\title{
Pengembangan Asesmen Kemampuan Berpikir Kritis Materi Sistem Sirkulasi untuk Siswa SMA Kelas XI
}

\section{Development of Critical Thingking Assesment of Circulation System Material for Grade XI High School Students}

\author{
Miftahussa'adiah, Heffi Alberida, Dezi Handayani \\ Program Studi Pendidikan Biologi, Universitas Negeri Padang, Sumatera Barat. *Corespondent email: \\ miftahussaadiah301193@gmail.com
}

Received: 01 June 2020 | Accepted: 10 July 2020 | Published: 20 July 2020

\begin{abstract}
Abstrak. Kemampuan berpikir kritis perlu dikembangkan. Siswa yang berpikir kritis tidak hanya menerima informasi yang diperoleh, namun dapat menggunakan informasi tersebut untuk menyelesaikan permasalahannya. Kemampuan berpikir kritis dapat dilatih dengan memberikan asesmen yang berada pada tingkat kognitif $\mathrm{C}_{4}-\mathrm{C}_{6}$. Penelitian ini bertujuan untuk menghasilkan asesmen kemampuan berpikir kritis pada materi sistem sirkulasi yang valid dan praktis. Penelitian menggunakan model pengembangan 4-D yang terdiri dari tahap define, design, dan develop. Instrumen pengumpulan data berupa angket uji validitas dan uji praktikalitas (validitas logis), serta soal multiple choice with written justifification (pilihan ganda dengan menuliskan argumen). Data dianalisis dengan menggunakan statistik deskriptif. Penelitian ini menghasilkan asesmen berpikir kritis untuk materi sistem sirkulasi yang valid dan praktis. Hasil uji validitas menunjukkan soal valid (secara logis dan empiris). Reliabilitas soal tinggi yaitu 0,61 , tingkat kesukaran soal antara 0,31 sampai dengan 0,70 , dan soal memiliki daya beda cukup, baik dan baik sekali. Daya beda cukup dengan persentase $10 \%$, daya beda baik dengan persentase $60 \%$, dan daya beda baik sekali dengan persentase 30\%. Berdasarkan hal tersebut, dapat disimpulkan telah dihasilkan asesmen kemampuan berpikir kritis yang valid secara logis dan empiris, praktis, reliabel dengan tingkat kesukaran sedang, dan memiliki daya pembeda yang baik.

Kata kunci: Asesmen, Berpikir Kritis, Kemampuan, Sistem Sirkulasi

Abstract. Critical thinking ability need to be developed. Students who are able to think critically not only receive information, but they also can use the information to solve the problem related to the information. Critical thinking ability can be trained by providing assessment which is at cognitive level of $C_{4}-C_{6}$. This study aims to generate critical thinking ability assessment, on the subject matter of the circulatory system, which is valid and practical. This research used model of development of the 4-D (define, design, develop and disseminate). The data collection instruments are questionnaires of validity test and practicalities test (logical validity), and multiple choice questions with written justification (multiple choice questions are required to write an argument). Data were analyzed using descriptive statistics. Validity test results show that the questions are valid (logically and empirically). Reliability of the the questions is quite high, at 0.61, about the difficulty level is between 0.31 up to 0.70, and the questions have three different power amongs fair (10\%), good (60\%) and excellent (30\%). It can be concluded that the assessment of critical thinking ability is valid logically and empirically, practical, reliable (with medium difficulty level), and good different power.

Keyword: Assessment, Critical Thinking, Ability, Circulation System
\end{abstract}

\section{PENDAHULUAN}

Biologi merupakan salah satu disiplin ilmu yang mempelajari seluk-beluk kehidupan. Pembelajaran biologi akan hidup dan menarik jika dapat menggerakkan atau mengaktifkan daya pikir siswa (Lufri, 2009), yaitu dengan cara mengajak siswa berpikir kritis. Berpikir kritis merupakan kemampuan untuk berpikir reflektif dan independen (Lau dan Chan, 2016), menjajaki (explore) suatu masalah, mengidentifikasi pertanyaan, menganalisa dan mengevaluasi 
semua informasi (Duron, et al., 2006; Facione, 2013), serta dapat menggunakan data dan mensintesis (Greenstein, 2012).

Kemampuan berpikir kritis sangat penting diterapkan (Halpern dan Marin, 2011; Hosnan, 2014). Hal ini sesuai dengan penelitian yang dilakukan oleh Warouw, et al., (2012) tentang persepsi guru biologi terhadap pembelajaran yang memberdayakan kemampuan berpikir kritis di 12 SMP Negeri dan Swasta Tondano, hasilnya yaitu dari 27 orang guru menyatakan penerapan berpikir kritis dalam pembelajaran biologi sangat penting $(11,11 \%)$, penting $(51,85 \%)$, kurang penting $(0 \%)$, dan $(37,04 \%)$ tidak memberikan jawaban. Berpikir kritis penting agar siswa tidak hanya menerima informasi, tetapi juga dapat mengolah dan menggunakan informasi yang diperolehnya. Artinya, semakin banyak informasi yang diterima maka ilmu pengetahuannya juga semakin meningkat (Hunter 1965) sehingga dapat mempersiapkan siswa menghadapi masa depan (Tilaar, 2011). Peran guru dalam hal ini yaitu guru dalam mengajar tidak hanya berfokus pada pemahaman konsep, namun membuat konsep-konsep tersebut menjadi alat untuk mengembangkan kemampuan berpikir kritis (Permendikbud, 2014).

Kemampuan berpikir kritis dapat dinilai dengan asesmen berpikir kritis. Menurut Ennis (2001), asesmen kemampuan berpikir kritis adalah kegiatan yang dilakukan guru untuk memperoleh informasi kemampuan berpikir kritis siswa yang dapat dinilai dengan instrumen asesmen tes yang dikembangkan dari aspek dan indikator berpikir kritis. Indikator yang digunakan dalam penelitian ini terdiri dari lima aspek yaitu; (1) aspek memberikan penjelasan sederhana (indikator menganalisis argumen, bertanya dan menjawab pertanyaan); (2) aspek membangun kemampuan dasar (indikator mempertimbangkan apakah sumber dapat dipercaya); (3) aspek menyimpulkan (indikator menginduksi dan mempertimbangkan hasil induksi serta membuat dan menentukan hasil pertimbangan); (4) aspek memberikan penjelasan lanjut (indikator mengidentifikasi asumsi-asumsi); (5) aspek mengatur strategi dan taktik (indikator menentukan suatu tindakan) (Ennis, 2011).

Asesmen kemampuan berpikir kritis terbagi atas asesmen secara langsung yaitu nilai yang diperoleh siswa secara kuantitatif dan secara tidak langsung yang dapat dilihat selama proses pembelajaran. Kedua asesmen tersebut diperlukan dalam proses pembelajaran (Fisher, 2009). Asesmen kemampuan berpikir kritis secara langsung penting dilakukan dalam kegiatan pembelajaran yaitu untuk mendiagnosis tingkat berpikir kritis siswa, memberikan umpan balik tentang kemampuan berpikir kritis siswa, memotivasi siswa agar memiliki kemampuan berpikir kritis lebih baik, dan sebagai informasi pada guru (Ennis, 2001).

Berdasarkan hasil wawancara dengan salah seorang guru biologi di SMA Negeri 1 Lubuk Alung pada tanggal 12 November 2015, terungkap bahwa asesmen kemampuan berpikir kritis yang dilakukan hanya asesmen secara tidak langsung yaitu melalui bertanya dan problem solving, serta kebanyakan guru menganggap asesmen kemampuan berpikir kritis siswa dapat dilihat dari nilai ujian harian.

Hasil analisis tingkat kognitif soal ujian harian 1 (materi sel dan jaringan tumbuhan) kelas XI di SMA Negeri 1 Lubuk Alung yang dibuat dalam bentuk esai dan objektif masih berada pada tingkat $\mathrm{C}_{1}-\mathrm{C}_{3}\left(\mathrm{C}_{1}\right.$ : pengetahuan, $\mathrm{C}_{2}$ : pemahaman, $\mathrm{C}_{3}$ : penerapan) yaitu dengan persentase $\mathrm{C}_{1}$ $(64 \%), \mathrm{C}_{2}(20 \%), \mathrm{C}_{3}(16 \%)$, dan persentase untuk tingkat $\mathrm{C}_{4}-\mathrm{C}_{6}\left(\mathrm{C}_{4}\right.$ : analisis, $\mathrm{C}_{5}$ : sintesis, $\mathrm{C}_{6}$ : evaluasi) yaitu $0 \%$. Berdasarkan hasil tersebut, soal ujian harian atau tes yang diberikan kurang mampu mengembangkan kemampuan berpikir kritis siswa. Berpikir kritis identik dengan soal yang berada pada tingkat kognitif $\mathrm{C}_{4}-\mathrm{C}_{6}\left(\mathrm{C}_{4}\right.$ : menganalisis, $\mathrm{C}_{5}$ : mensintesis, dan $\mathrm{C}_{6}$ : 
mengevaluasi) pada taksonomi Bloom (Ennis, 2001) dan dapat diukur pada semua materi. Tujuan penelitian ini yaitu untuk menghasilkan asesmen kemampuan berpikir kritis pada materi sistem sirkulasi yang valid dan praktis.

\section{METODE PENELITIAN}

Jenis penelitian ini adalah penelitian pengembangan (Reseach and Development). Penelitian ini dilakukan di Fakultas Matematika dan Ilmu Pengetahuan Alam (FMIPA) Universitas Negeri Padang (UNP). Produk yang dihasilkan berupa asesmen kemampuan berpikir kritis yang telah diujicobakan pada semester genap Tahun Pelajaran 2015/2016 pada tanggal 2 Februari 2016 di SMA Negeri 1 Lubuk Alung. Subjek penelitian ini terdiri dari validator dan siswa sebagai subjek uji coba. Objek penelitian ini adalah asesmen kemampuan berpikir kritis materi sistem sirkulasi untuk siswa SMA kelas XI.

Asesmen kemampuan berpikir kritis berupa soal pilihan ganda (multiple choice) dengan menuliskan argumen terhadap jawaban yang dipilih yang dikembangkan dengan menggunakan 4-D Models yang terdiri dari empat tahap yaitu tahap define, design, develop, dan disseminate. Pada penelitian ini, tahap disseminate tidak dilakukan.

\section{Tahap pendefenisian (Define)}

Pada tahap ini dilakukan penetapan syarat pembelajaran dengan menganalisis kompetensi inti, kompetensi dasar dan bahan materi pembelajaran berdasarkan kurikulum 2013. Beberapa langkah yang dilakukan pada tahap define yaitu analisis masalah, analisis siswa, analisis tugas, analisis konsep, perumusan tujuan pembelajaran.

\section{Tahap perancangan (Design)}

Tujuan dari tahap ini adalah untuk menyiapkan asesmen kemampuan berpikir kritis materi sistem sirkulasi untuk siswa SMA kelas XI. Ada tiga langkah pada tahap ini yaitu: pemilihan aplikasi, pemilihan format, dan perancangan awal.

\section{Tahap pengembangan (Develop)}

Pada tahap ini bertujuan untuk menghasilkan perangkat pembelajaran yang sudah direvisi dan divalidasi berdasarkan masukan dari para ahli pendidikan yang meliputi:

\section{a. Uji validitas}

Validator pada penelitian ini terdiri dari tiga orang dosen biologi FMIPA UNP dan satu orang guru biologi SMAN 1 Lubuk Alung. Tanggapan dari validator berupa kritikan, masukan, dan saran digunakan sebagai dasar untuk merevisi asesmen kemampuan berpikir kritis yang telah dibuat. Hasil revisi asesmen digunakan dalam uji praktikalitas. Setelah dilakukan validasi logis, maka dilakukan validasi empiris setelah soal diujicobakan kepada 32 orang siswa kelas XI SMA Negeri 1 Lubuk Alung.

\section{b. Uji praktikalitas}

Uji praktikalitas dilakukan dengan memberikan angket kepada dua orang guru biologi di SMA Negeri 1 Lubuk Alung. Kegiatan ini dilakukan untuk mengetahui sejauh mana kemudahan melaksanakan tes, kemudahan pemeriksaan, dan terdapatnya petunjuk penggunaan asesmen kemampuan berpikir kritis oleh siswa dan guru. 


\section{c. Uji reliabilitas asesmen kemampuan berpikir kritis}

Reliabilitas asesmen kemampuan berpikir kritis didapatkan setelah soal diujicobakan dan dicari nilai relibailitasnya. Suatu tes dikatakan reliabel (reliabilitas tinggi) jika $r_{11}$ sama dengan atau lebih besar dari 0,70 .

\section{d. Tingkat kesukaran soal}

Tingkat kesukaran adalah tingkat mudah atau sulitnya soal dijawab siswa. Soal yang baik adalah soal yang tidak telalu mudah atau tidak terlalu sukar. Data yang diperoleh setelah asesmen diujikan dengan menggunakan rumus yang sudah ada.

\section{e. Daya pembeda soal}

Daya pembeda soal adalah kemampuan suatu soal untuk membedakan antara siswa berkemampuan tinggi dengan siswa berkemampuan rendah.

\section{Instrumen Pengumpulan Data}

Instrumen pengumpulan data yaitu berupa angket uji validitas yang diisi oleh dosen dan guru, serta angket uji praktikalitas yang diisi oleh guru Biologi SMAN 1 Lubuk Alung, disusun menurut skala Likert seperti pada Tabel 1. dibawah ini.

Tabel 1. Kriteria pemberian skor jawaban validitas

\begin{tabular}{cc}
\hline Skor & Kriteria \\
\hline 4 & Sangat Setuju (SS) \\
3 & Setuju (S) \\
2 & Tidak Setuju (TS) \\
1 & Sangat Tidak Setuju (STS) \\
\hline
\end{tabular}

Sumber: Arikunto, (2009)

\section{Teknik Analisis Data}

Analisis data penelitian ini dilakukan dengan menggunakan statistik deskriptif. Teknik ini akan mendeskripsikan hasil uji validitas, uji praktikalitas, dan uji reliabilitas asesmen kemampuan berpikir kritis.

\section{Analisis validitas asesmen kemampuan berpikir kritis}

\section{a. Validitas logis}

Analisis validitas asesmen kemampuan berpikir kritis berupa syarat kelayakan isi, kebahasaan, penyajian, dan kegrafikan berdasarkan lembar validasi dilakukan dengan cara:

1) Memberikan skor jawaban dengan skala Likert (Tabel 1)

2) Menentukan skor tertinggi Skor tertinggi $=$ jumlah validator $\mathrm{x}$ skor maksimum.

3) Menentukan jumlah skor dari masing-masing validator dengan menjumlahkan semua skor yang diperoleh dari masing-masing indikator.

4) Menentukan skor yang diperoleh dengan menjumlahkan skor dari masing-masing validator.

5) Penentuan nilai validitas dengan cara:

Nilai validitas $=\frac{\text { jumlah skor yang diperoleh }}{\text { jumlah skor tertinggi }} \times 100 \%$

6) Memberikan asesmen validitas dengan kriteria berikut ini. 
Tabel 2. Kriteria validitas asesmen

\begin{tabular}{cc}
\hline Persentase $(\%)$ & Kriteria \\
\hline $90-100$ & Sangat Valid \\
$80-89$ & Valid \\
$60-79$ & Cukup Valid \\
$0-59$ & Tidak Valid \\
\hline
\end{tabular}

Sumber: Purwanto, (2009)

\section{b. Validitas Empiris}

Data validitas empiris diperoleh setelah soal diujikan kepada siswa berdasarkan hasil analisis butir soal lembar jawaban yang telah diisi siswa.

1) Memberi tanda silang (X) pada lembar jawaban yang dianggap salah dan memberi tanda ceklis $(\sqrt{ })$ pada lembar jawaban yang dianggap benar.

Tabel 3. Kriteria skor penilaian pada lembar jawaban asesmen berpikir kritis

\begin{tabular}{ccc}
\hline Skor & Kriteria & Keterangan \\
\hline 4 & Sangat Benar & Objektif dan Argumen \\
3 & Benar & Argumen \\
2 & Cukup Benar & Objektif \\
1 & Tidak Benar & Menjawab \\
\hline
\end{tabular}

Keterangan: skor siswa yang tidak menjawab soal adalah 0 (nol).

2) Skor tiap lembar jawaban (tiap siswa) dijumlahkan dan diurutkan berdasarkan skor tertinggi hingga terendah.

Uji validitas empiris dianalisis dengan rumus sebagai berikut.

$$
r_{x y}=\frac{N \sum X Y-\left(\sum X\right)\left(\sum Y\right)}{\sqrt{\left\{N \sum X^{2}-\left(\sum X\right)^{2}\right\}\left\{N \sum Y^{2}-\left(\sum Y\right)^{2}\right\}}}
$$

Dimana : $\mathrm{r}_{\mathrm{xy}}=$ validitas soal; $\mathrm{X}=$ hasil tes yang dicari validitasnya; $\mathrm{Y}=$ hasil tes standar.

\section{Analisis praktikalitas asesmen kemampuan berpikir kritis}

Data uji praktikalitas penggunaan asesmen kemampuan berpikir kritis dianalisis dengan persentase (\%), menggunakan rumus berikut.

$$
\text { Nilai praktikalitas }=\frac{\text { jumlah semua skor }}{\text { skor tertinggi }} \times 100 \%
$$

Tabel 4. Kriteria praktikalitas asesmen

\begin{tabular}{cc}
\hline Persentase $(\%)$ & Kriteria \\
\hline $90-100$ & Sangat Praktis \\
$80-89$ & Praktis \\
$60-79$ & Cukup Praktis \\
$0-59$ & Tidak Praktis \\
\hline
\end{tabular}

Sumber: Purwanto, (2009) 


\section{Analisis reliabilitas asesmen kemampuan berpikir kritis}

Analisis reliabilitas untuk soal pilihan ganda dapat diketahui dengan rumus $K R_{20}$ sebagai berikut.

$$
r_{11}=\left(\frac{n}{n-1}\right)\left(S_{t}^{2}-\frac{\sum p_{i} q_{i}}{S_{t}^{2}}\right)
$$

Nilai $S_{t}^{2}$ dapat dicari dengan rumus berikut ini.

$$
S_{t}^{2}=\frac{\sum X_{t}^{2}}{N}
$$

Dalam menggunakan rumus diatas, terlebih dahulu diketahui nilai dari $\sum X_{t}^{2}$ dengan menggunakan rumus berikut ini.

$$
\sum X_{t}^{2}=\sum X_{t}^{2}-\left(\frac{\sum X_{t}}{N}\right)^{2}
$$

Dimana: $r_{11}=$ koefisien reliabilitas tes; $\mathrm{n}=$ banyaknya butir item yang dikeluarkan dalam tes; $1=$ bilangan konstan; $\mathrm{N}=$ jumlah testee; $\sum \mathrm{X}=$ skor total masing-masing testee; $\mathrm{p}=$ jumlah skor setiap butir soal dibagi jumlah testee; q : 1-p ; $S_{t}{ }^{2}=$ varian total (Sudijono, 2011). Suatu tes dikatakan reliabel (memiliki reliabilitas yang tinggi) bila $r_{11}$ sama dengan atau lebih besar daripada 0,70 , sedangkan bila lebih kecil dari 0,70 maka belum memiliki reliabilitas yang tinggi.

\section{Tingkat kesukaran}

Untuk soal pilihan ganda, tingkat kesukaran ditentukan dengan rumus:

$$
\mathrm{TK}=\frac{\text { jumlah siswa yang menjawab butir tersebut dengan benar }}{\text { jumlah seluruh testee }}
$$

Tabel 5. Kriteria tingkat kesukaran soal

\begin{tabular}{cc}
\hline Indeks & Kriteria \\
\hline $0,00-0,30$ & Sukar \\
$0,31-0,70$ & Sedang \\
$0,71-1,00$ & Mudah \\
\hline
\end{tabular}

Sumber: Arikunto, (2009)

\section{Daya pembeda}

Daya pembeda untuk soal pilihan ganda dapat diketahui dengan menggunakan rumus:

$$
\mathrm{DP}=\frac{\mathrm{BA}}{\mathrm{JA}}-\frac{\mathrm{BB}}{\mathrm{JB}}
$$

Dimana : BA = jumlah siswa kelompok atas yang menjawab benar butir tersebut; JA = jumlah siswa yang termasuk kelompok atas; $\mathrm{BB}=$ jumlah siswa kelompok bawah yang menjawab benar butir tersebut; JB = jumlah siswa yang termasuk kelompok bawah.

Tabel 6. Klasifikasi daya pembeda soal

\begin{tabular}{cc}
\hline Indeks & Kriteria \\
\hline $0,00-0,20$ & Jelek (poor) \\
$0,21-0,40$ & Cukup (satistifactory) \\
$0,41-0,70$ & Baik (good) \\
$0,71-1,00$ & Baik Sekali (excellent) \\
\hline
\end{tabular}

Sumber: Arikunto, (2009) 


\section{HASIL DAN PEMBAHASAN \\ Define (Tahap Pendefinisian)}

\section{Analisis masalah}

Analisis masalah berdasarkan analisis pada tingkat kognitif soal ujian harian 1 tentang sel dan jaringan tumbuhan yang berbentuk esai dan objektif. Berdasarkan analisis tersebut, soal yang diujikan masih dominan berada pada tingkat kognitif pengetahuan $\left(\mathrm{C}_{1}\right)$ yaitu $64 \%$, pemahaman (C2) yaitu 20\%, dan penerapan (C3) yaitu $16 \%$.

\section{Hasil analisis siswa}

Berdasarkan observasi, diketahui bahwa umumnya siswa yang duduk di kelas XI berumur 17-18 tahun. Menurut teori belajar Piaget (1983) dalam Budiningsih (2008) pada tahap operasional formal umur 11/12-18 tahun ciri pokok perkembangannya sudah mampu berpikir abstrak, mampu berpikir logis, mampu menarik kesimpulan, menafsirkan, dan mengembangkan hipotesis. Dengan demikian, siswa yang duduk di kelas XI telah mampu mengembangkan kemampuan berpikir kritisnya.

\section{Hasil analisis tugas}

Analisis tugas lebih difokuskan pada perincian Kompetensi Inti (KI) dan Kompetensi Dasar (KD) untuk materi sistem sirkulasi yang dijabarkan menjadi indikator.

\section{Hasil analisis konsep}

Analisis konsep dilakukan dengan mengidentifikasikan konsep utama dari materi sistem sirkulasi. Konsep utama pada materi ini yaitu mengenai hubungan antara struktur dan fungsi dari komponen darah serta kaitannya dengan bioproses dan kelainan yang mungkin terjadi, serta hubungan antara struktur dan fungsi dari organ penyusun sistem sirkulasi serta kaitannya dengan bioproses dan kelainan yang mungkin terjadi. Konsep ini yang harus dikuasai oleh siswa untuk mengerjakan asesmen kemampuan berpikir kritis ini.

\section{Design (Tahap Perancangan)}

\section{Pemilihan aplikasi}

Asesmen kemampuan berpikir kritis ini dibuat dengan menggunakan aplikasi Microsoft Word 2010.

\section{Pemilihan format}

Format yang dipilih memenuhi kriteria menarik, jelas, dan tidak mengganggu siswa dalam mengerjakan asesmen kemampuan berpikir kritis.

\section{Perancangan awal}

Asesmen kemampuan berpikir kritis yang dikembangkan berjumlah 30 soal pilihan ganda dengan meminta siswa untuk memberikan argumen terhadap jawabannya. Bentuk asesmen kemampuan berpikir kritis yang dihasilkan adalah sebagai berikut.

\section{a. Cover asesmen}

Cover asesmen terdiri dari cover depan dan cover halaman kedua. Cover depan asesmen memuat identitas asesmen yang meliputi judul, jenis materi, dan nama pengarang. Bagian cover dirancang dengan dominasi warna merah dan dilengkapi dengan gambar sel darah untuk mewakili materi sistem sirkulasi. Tulisan pada cover depan ditulis dengan jenis dan ukuran 
tulisan yaitu Bradley Hand ITC 22pt dan Britannic Bold 28pt (Gambar 1.a). Cover halaman kedua memuat judul, logo UNP, nama penyusun, nama pembimbing, dan nama validator yang telah memvalidasi asesmen kemampuan berpikir kritis. Jenis tulisan cover halaman kedua ini yaitu Comic Sans MS dengan ukuran huruf 20pt, Perpetua dengan ukuran huruf 16pt, dan Times New Roman dengan ukuran 16pt (Gambar 1.b).

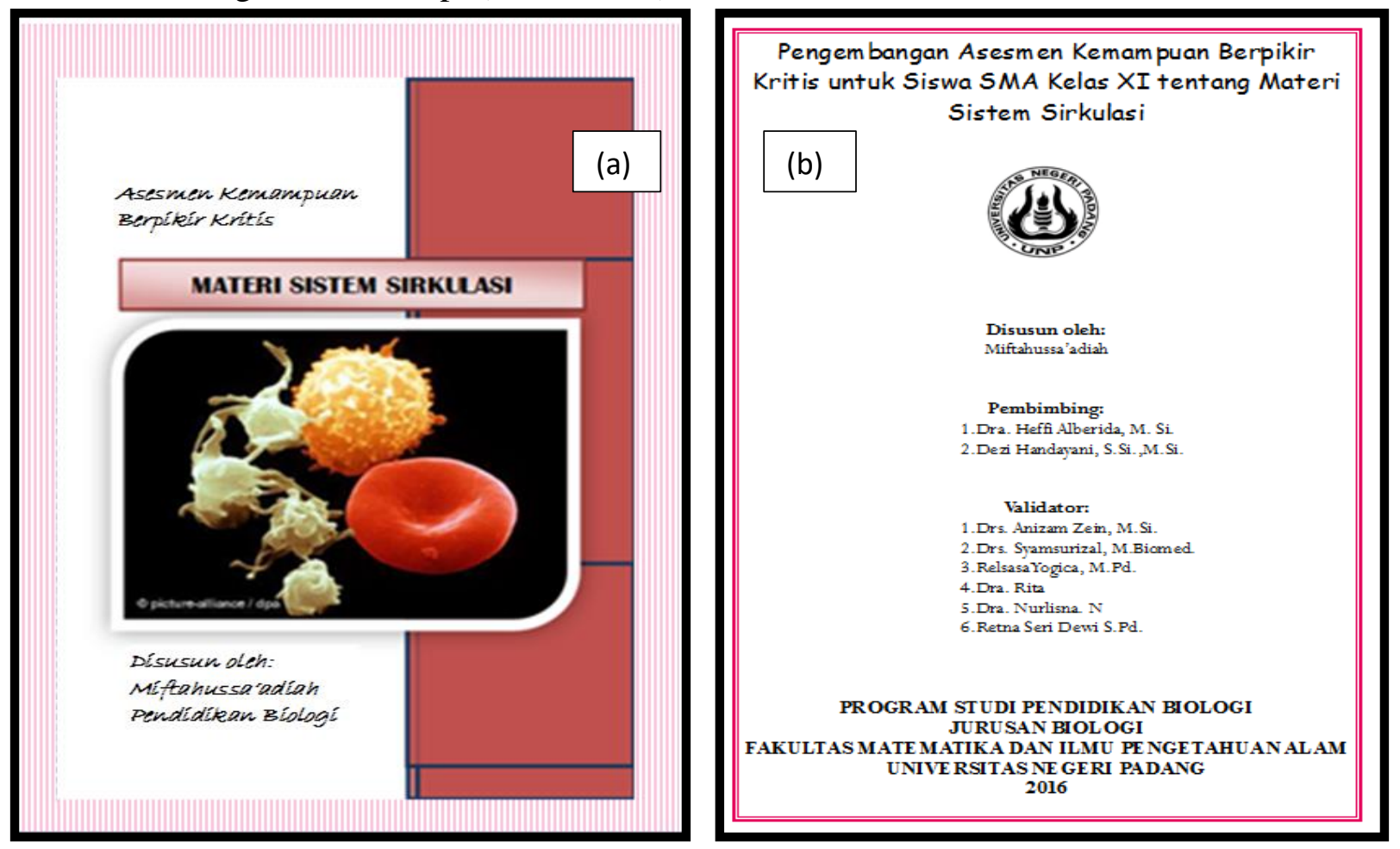

Gambar 1. Visualisai cover: (a) cover depan; (b) cover halaman kedua

\section{b. Petunjuk pengerjaan asesmen}

Petunjuk pengerjaan asesmen berisi pedoman dan aturan untuk mengerjakan asesmen kemampuan berpikir kritis. Petunjuk ini terdiri dari petunjuk umum dan khusus. Petunjuk umum digunakan sebagai pedoman untuk mengerjakan soal secara umum, dan petunjuk khusus digunakan sebagai pedoman untuk menjawab soal secara khusus.

Tujuan diberikan petunjuk ini yaitu agar siswa mudah untuk mengerjakan soal. Petunjuk pengerjaan asesmen kemampuan berpikir kritis ditulis dengan Microsoft Word 2010 dengan jenis tulisan Times New Roman dan ukurannya 12pt.

\section{c. Tampilan asesmen kemampuan berpikir kritis}

Tampilan asesmen kemampuan berpikir kritis ini berupa soal pilihan ganda sebanyak 30 butir soal dan siswa harus memberikan argumen terhadap jawaban yang dipilihnya. Oleh karena itu, tampilan asesmen ini juga memuat kotak yang meminta siswa untuk menulis argumen pada lembar jawaban yang disediakan. Jenis tulisan yang digunakan adalah Times New Roman dengan ukuran $12 \mathrm{pt}$. Ukuran kotak yang berada dibawah soal yaitu $(1,5 \times 15) \mathrm{cm}$.

\section{Develop (Tahap Pengembangan)}

\section{Validitas logis}

Asesmen kemampuan berpikir kritis yang dikembangkan sudah valid berdasarkan empat aspek yaitu materi, konstruksi, bahasa dan kemampuan berpikir kritis, secara rinci dapat dilihat pada tabel di bawah ini. 
Tabel 7. Hasil Validasi Asesmen Kemampuan Berpikir Kritis

\begin{tabular}{clcc}
\hline No & \multicolumn{1}{c}{ Komponen Penilaian } & Nilai Validasi & Kriteria \\
\hline 1 & Materi & $96,53 \%$ & Sangat valid \\
2 & Konstruksi & $88,02 \%$ & Valid \\
3 & Bahasa/Budaya & $84,37 \%$ & Valid \\
4 & Asesmen Kemampuan Berpikir Kritis & $91,67 \%$ & Sangat valid \\
\hline \multicolumn{2}{c}{ Rata-rata } & $90,14 \%$ & Sangat valid \\
\hline
\end{tabular}

Dilihat dari segi materi, asesmen kemampuan berpikir kritis dinyatakan sangat valid, artinya soal sesuai dengan Kurikulum 2013 dan telah sesuai dengan Kompetensi Inti dan Kompetensi Dasar. Depdiknas (2008) menyatakan, bahwa materi yang dikembangkan harus sesuai dengan tuntutan Kompetensi Dasar dan Indikator. Kriteria sangat valid pada asesmen kemampuan berpikir kritis ini menunjukkan bahwa materi pada soal pilihan ganda berargumen dapat digunakan untuk mengukur kemampuan berpikir kritis siswa.

Dilihat dari aspek konstruksi, asesmen kemampuan berpikir kritis bentuk soal pilihan ganda sudah valid. Konstruksi soal ini berhubungan dengan rumusan soal yang diberikan jelas dan harus berkaitan dengan materi yang ditanyakan sehingga tidak menimbulkan kerancuan bagi siswa. Sani (2014) menyatakan bahwa pokok soal harus dirumuskan secara jelas dan tegas serta harus berkaitan dengan materi yang ditanyakan. Ditinjau dari segi bahasa, asesmen ini juga sudah valid, artinya soal pilihan ganda yang dibuat sudah menggunakan bahasa yang sesuai dengan kaidah Bahasa Indonesia dan komunikatif. Hal ini senada dengan pendapat Sani (2014) menyatakan, setiap soal harus menggunakan bahasa yang sesuai dengan kaidah Bahasa Indonesia dan tidak menggunakan kata yang berlaku untuk daerah setempat jika soal digunakan secara nasional.

Selanjutnya dilihat dari segi kemampuan berpikir kritis, asesmen ini memiliki kriteria sangat valid. Artinya, soal pilihan ganda berargumen bisa dijadikan sebagai asesmen kemampuan berpikir kritis yang dapat mengaktifkan perkembangan kemampuan berpikir kritis siswa. Kemampuan berpikir kritis dapat dikembangkan dengan sengaja (Muhfahroyin, 2010) karena berpikir kritis dapat dipelajari dan diajarkan (Facione, 2010). Secara keseluruhan, validasi soal asesmen dari validator didapatkan nilai rata-rata sebesar 90,14\% dengan kriteria sangat valid, sehingga asesmen ini dapat digunakan dalam penilaian biologi khususnya materi sistem sirkulasi. Asesmen yang digunakan secara berkesinambungan dan sistematis akan memberikan manfaat berupa informasi pada guru (Ennis, 2001; Mumpuniarti, 2014) dan siswa untuk mengukur tingkat keberhasilan siswa berpikir kritis dalam mempelajari materi (Wulandari et al., 2013).

\section{Praktikalitas Asesmen Kemampuan Berpikir Kritis}

Asesmen kemampuan berpikir kritis yang dihasilkan praktis digunakan oleh guru berdasarkan tiga aspek (Tabel 8.). Uji praktikalitas dilakukan oleh dua orang guru SMAN 1 Lubuk Alung. Ditinjau dari aspek pelaksanaan, asesmen kemampuan berpikir kritis ini dinilai praktis. Hal ini menunjukkan bahwa asesmen ini tidak menuntut peralatan yang banyak dan memberikan kebebasan pada siswa untuk mengerjakan soal yang lebih mudah. Hal ini sesuai dengan pendapat Arikunto (2009) bahwa tes yang praktis adalah tes yang mudah dilaksanakan, 
seperti tidak menuntut peralatan yang banyak dan memberikan kebebasan kepada siswa untuk mengerjakan terlebih dahulu bagian yang dianggap mudah oleh siswa.

Tabel 8. Hasil Uji Praktikalitas Asesmen Kemampuan Berpikir Kritis

\begin{tabular}{clcl}
\hline No & \multicolumn{1}{c}{ Aspek } & Nilai Praktis & Kriteria \\
\hline 1 & Kemudahan Penggunaan & $87,50 \%$ & Praktis \\
2 & Efisiensi waktu & $87,50 \%$ & Praktis \\
3 & Keterterapan asesmen kemampuan berpikir kritis & $87,50 \%$ & Praktis \\
\hline & Rata-rata & $87,50 \%$ & Praktis \\
\hline
\end{tabular}

Selanjutnya ditinjau dari aspek pemeriksaan, soal asesmen kemampuan berpikir kritis ini praktis karena soal dilengkapi dengan kunci jawaban dan lembar jawaban. Artinya, guru akan lebih mudah memeriksa jawaban siswa sehingga waktu untuk memeriksa asesmen ini lebih efisien. Hal ini senada dengan pendapat Arikunto (2009) bahwa tes yang praktis adalah tes yang mudah pemeriksaannya, artinya bahwa tes itu dilengkapi dengan kunci jawaban maupun pendoman skoringnya dan untuk soal bentuk objektif, pemeriksaannya akan lebih mudah dilakukan jika dikerjakan oleh siswa dalam lembar jawaban.

Dilihat dari aspek petunjuk soal, asesmen ini dikategorikan praktis karena tes tersebut dilengkapi dengan petunjuk yang jelas. Arikunto (2009) menyatakan, bahwa tes yang praktis adalah tes yang dilengkapi dengan petunjuk yang jelas sehingga dapat diberikan atau diawali oleh orang lain. Secara keseluruhan didapatkan nilai praktikalitas oleh guru sebesar 87,50\% dengan kriteria praktis. Asesmen ini praktis digunakan guru untuk mengukur kemampuan berpikir kritis siswa karena tidak menuntut peralatan yang banyak, memudahkan dalam pemeriksaan dan dilengkapi dengan petunjuk pengerjaan yang jelas. Petunjuk penggunaan, tampilan dan tata letak, dan kunci jawaban memiliki kriteria sangat praktis, artinya produk asesmen tersebut telah dapat digunakan (Dharmawati et al., 2016).

\section{Analisis butir soal}

Asesmen kemampuan berpikir kritis soal pilihan ganda yang dihasilkan sudah valid berdasarkan validitas empiris, dimana $r_{x y}$ lebih besar dari $r$ tabel. Arikunto (2009) menyatakan, bahwa sebuah item soal dikatakan valid apabila mempunyai dukungan yang besar terhadap skor total. Analisis butir soal secara ringkas pada Tabel 9 dibawah ini.

Tabel 9. Analisis Butir Soal

\begin{tabular}{cccc}
\hline Validitas Empiris & Reliabilitas & Tingkat kesukaran (\%) & Daya pembeda (\%) \\
\hline Valid & Reliabel & Sukar $(0 \%) ;$ Sedang & Jelek (0\%); Cukup (10\%) \\
$(0,449-0,726)$ & $(0,610)$ & $(100 \%) ;$ Mudah $(0 \%)$ & Baik (60\%); Baik Sekali \\
& & & $(30 \%)$ \\
\hline
\end{tabular}

Asesmen kemampuan berpikir kritis yang dihasilkan sudah reliabel, yaitu $\mathrm{r}_{11}$ adalah 0,61 lebih besar dari $r_{\text {tabel }}$ yaitu 0,349. Berdasarkan hal tersebut, asesmen yang dihasilkan memiliki reliabilitas yang tinggi. Asesmen kemampuan berpikir kritis dikatakan reliabel bila asesmen ini akan memberikan hasil yang sama jika di teskan pada kelompok yang sama pada waktu atau kesempatan yang berbeda. Suatu tes dikatakan reliabel jika memiliki hasil ketetapan dalam tes (Arikunto, 2009) dan konsistensi jawaban siswa berkategori baik dan kualitas butir soal yang dikembangkan memiliki aspek reliabilitas tinggi (Nawawi dan Wijayanti, 2018). Asesmen kemampuan berpikir kritis yang dihasilkan berada pada tingkat kesukaran sedang. Artinya tidak 
ada soal yang terlalu sulit dan terlalu mudah untuk siswa. Soal yang baik adalah soal yang tidak terlalu mudah atau tidak terlalu sukar. Soal yang terlalu mudah tidak merangsang siswa untuk mempertinggi usaha memecahkannya. Sebaliknya soal yang terlalu sukar akan menyebabkan siswa menjadi putus asa dan tidak mempunyai semangat untuk mencoba lagi (Arikunto, 2009).

Asesmen berpikir kritis akan menghasilkan informasi yang optimal jika diberikan pada siswa yang memiliki keterampilan berpikir kritis level sedang (Nawawi dan Wijayanti, 2018). Asesmen ini memiliki daya pembeda cukup sebanyak 10\%, daya pembeda baik sebanyak $60 \%$, dan daya pembeda baik sekali sebanyak 30\%. Daya pembeda soal dapat membedakan antara siswa yang memiliki kemampuan tinggi dengan siswa yang memiliki daya kemampuan rendah. Soal dikatakan memiliki daya pembeda yang baik jika nilainya 0,4 sampai 0,7 . Berdasarkan analisis daya pembeda, dapat dikatakan asesmen ini memiliki daya beda yang baik sehingga soal yang dikerjakan oleh siswa dapat berfungsi secara optimal (Nawawi dan Wijayanti, 2018).

Berdasarkan analisis butir soal (validitas empiris, reliabilitas, tingkat kesukaran, dan daya pembeda), asesmen yang dikembangkan dapat digunakan untuk mengukur kemampuan berpikir kritis siswa dalam pembelajaran biologi khususnya pada materi sistem sirkulasi. Pemberdayaan kemampuan berpikir kritis dalam kegiatan pembelajaran tentunya akan membekali siswa untuk menjadi problem solver, objektif terhadap permasalahan yang ada (Muhfahroyin, 2010), dan dapat menghasilkan ide yang baru, tidak biasa, dan berbeda dari ide sebelumnya (Istianah, 2013).

\section{KESIMPULAN}

Berdasarkan penelitian yang telah dilakukan, dapat disimpulkan bahwa telah dihasilkan asesmen kemampuan berpikir kritis pada materi sistem sirkulasi yang valid secara logis dan empiris, praktis, memiliki nilai reliabilitas yang tinggi, dengan tingkat kesukaran sedang, dan daya pembeda yang baik.

\section{UCAPAN TERIMA KASIH}

Peneliti mengucapkan terimakasih kepada Ibu Dra. Heffi Alberida, M.Si., sebagai penasehat akademik dan pembimbing I dan Ibu Dezi Handayani, S.Si, M.Si sebagai pembimbing II. Bapak Drs. Anizam Zein, M.Si., Bapak Drs. Anizam Zein, M.Si., Bapak Relsas Yogica, M.Pd., Bapak Drs. Syamsurizal, M. Biomed., Drs. Azwir Alwi, M.Si., Dra. Rita., Dra. Nurlisna. N., Retna Seri Dewi, S.Pd. sebagai validator dalam penelitian ini.

\section{REFERENSI}

Arikunto, S. 2009. Dasar-dasar Evaluasi Pendidikan. Bumi Aksara, Jakarta. 308 hal.

Budiningsih, A. 2008. Belajar dan Pembelajaran. Rineka Cipta, Jakarta. 128 hal.

Depdiknas. 2008. Panduan Pengembangan Bahan Ajar. Direktorat Jendral Manajemen Pendidikan Dasar dan Menengah, Jakarta.

Dharmawati, Rahayu, S., dan Mahanal, S. 2016. Pengembangan Instrumen Asesmen Berpikir Kritis untuk siswa SMP Kelas VII pada Materi Interaksi Makhluk Hidup dengan Lingkungan. Jurnal Pendidikan: Teori, Penelitian, dan Pengembangan. 1(8): 1598-1606. 
Duron, R., Limbach, B., and Waugh, W. 2006. Critical Thingking Framework for any Discipline. International Journal of Teaching and Learning in Higher Education. 17(2): 160-166.

Ennis, R. H. 2001. Critical Thingking Assesment. The University of Illionis, Urbana-Champaign.

Ennis, R. H. 2011. The Nature of Critical Thinking: An Outline of Critical Thinking Dispositionsand Abilities. The University of Illinois, pp 1-8. https://education.illinois.edu/docs/default-source/faculty-documents/robertennis/thenatureofcriticalthinking_51711_000.pdf

Facione, P. A. 2010. Critical Thinking: What It Is ang Why It Counts. Insight Assesment. 1-30pp

Facione, P. A. 2013. Critical Thingking: What it is and Why it Counts. Diunduh tanggal 30 April 2018. http://spu.edu/depts/health-sciences/grad/documents/CTbyFacione.pdf.

Fisher, A. 2009. Berpikir Kritis: Sebuah Pengantar. Erlangga, Jakarta. 256 hal.

Greenstein, L. 2012. Assessing 21st Century Skills: A Guide to Evaluating Mastery and Authentic Learning. Diunduh tanggal 30 April 2018. https://uk.sagepub.com/engb/asi/assessing-21st-century-skills/book237748.

Halpern, D. F., and Marin, L. M. 2011. Pedagogy for Deveoping Critical Thingking in Adolescents: Explicits Instruction Produces Greatest Gains. Thingking Skills and Creativity. 6: 1-13.

Hosnan, M. 2014. Pendekatan Saintifik dan Kontekstual dalam Pembelajaran Abad 21 Kunci Sukses Implementasi Kurikulum 2013. Ghalia, Jakarta. 456 hal.

Hunter, D. A. 1965. A Practical Guide to Critical Thingking: Deciding What to Do and Believe. John Wiley and Sons, Inc, Jersey. 256pp

Istianah, E. 2013. Meningkatkan Kemampuan Berpikir Kritis dan Kreatif Matematik dengan Pendekatan Model Eliciting Activities (MEAs) pada Siswa SMA. Infinity: Jurnal Ilmiah Program Studi Pendidikan STKIP Siliwangi Bandung. 2(1): 43-54.

Lau, J., and Chan, J. 2016. What is Critical Thinking?. Diunduh tanggal 24 Juli 2020. http://philosophy.hku.hk/think/critical/ct.php

Lufri. 2009. Pendidikan dan Pengajaran Biologi Bernuansa IESQ. UNP Press, Padang. 260 hal.

Muhfahroyin. 2010. Memberdayakan Kemampuan Berpikir Kritis Siswa melalui Pembelajaran Konstruktivistik. Jurnal Pendidikan dan Pembelajaran (JPP). 16(1): 88-93.

Mumpuniarti. 2014. Prosedur dan Mekanisme Penyelenggaraan Asesmen di Sekolah. Makalah disampaikan pada Pengabdian Masyarakat di depan Guru-guru Sekolah Luar Biasa Negeri Purworedjo, 5 Juni 2014.

Nawawi, S., dan Wijayanti, T. F. 2018. Pengembangan Asesmen Biologi berbasis Keterampilan Berpikir Kritis Terintegrasi Nilai Islam. Jurnal Inovasi Pendidikan IPA. 4(2): 136-148.

Permendikbud. 2014. Penilaian Hasil Belajar oleh Pendidik pada Pendidikan Dasar dan Pendidikan Menengah. Menteri Pendidikan Dan Kebudayaan Republik Indonesia, Jakarta.

Purwanto, M. N. 2009. Prinsip-prinsip dan Teknik Evaluasi Pengajaran. Remaja Rosdakarya, Bandung. 166 hal.

Sani, R. A. 2014. Pembelajaran Saintifik untuk Implementasi Kurikulum 2013. Bumi Aksara, Jakarta. 314 hal.

Sudijono, A. 2011. Pengantar Evaluasi Pendidikan. Rajawali Press, Jakarta. 488 hal. 
Tilaar, H. A. 2011. Pedagogik Kritis, Perkembangan Substansi, dan Perkembangannya di Indonesia. Rineka Cipta, Jakarta. 306 hal.

Warouw, W. M., Raturandang, Z. O., Sumakul, J., dan Jemy. 2012. Persepsi Guru Biologi Terhadap Pembelajaran yang Memberdayakan Kemampuan Berpikir Kritis dan Hasil Belajar Siswa di SMP Negeri dan Swasta Tondano. Seminar Nasional IX Pendidikan Biologi FKIP UNS.

Wulandari, D. T., Suyatna, A., dan Rosidin, U. 2013. Pengembangan Lembar Penilaian berbasis Keterampilan Berpikir Kritis. Jurnal Pembelajaran Fisika. 1(7): 43-54.

\section{Authors:}

Miftahussa'adiah, Program Studi Pendidikan Biologi, Universitas Negeri Padang, Sumatera Barat, Alamat: Jl. Prof. Dr. Hamka, Air Tawar Barat, Kecamatan Padang Utara, Kota Padang, Kodepos: 25171, Propinsi: Sumatera Barat, Negara: Indonesia, email: miftahussaadiah301193@gmail.com

Heffi Alberida, Program Studi Pendidikan Biologi, Universitas Negeri Padang, Sumatera Barat, Alamat: Jl. Prof. Dr. Hamka, Air Tawar Barat, Kecamatan Padang Utara, Kota Padang, Kodepos: 25171, Propinsi: Sumatera Barat, Negara: Indonesia, email: heffialberida @ fmipa.unp.ac.id

Dezi Handayani, Program Studi Pendidikan Biologi, Universitas Negeri Padang, Sumatera Barat, Alamat: Jl. Prof. Dr. Hamka, Air Tawar Barat, Kecamatan Padang Utara, Kota Padang, Kodepos: 25171, Propinsi: Sumatera Barat, Negara: Indonesia, email: dzhandayani@yahoo.com

This is an open-access article distributed under the terms of the Creative Commons Attribution License, which permits unrestricted use, distribution and reproduction in any medium, provided the original author and source are credited. (http://creativecommons.org/licenses/by/4.0/)

\section{How to cite this article:}

Miftahussa'adiah, Alberida, H., and Handayani, D. 2020. Development of critical thingking assesment of circulation system material for grade XI high school students. Simbiosa, 9(1):39-51. Doi. http://dx.doi.org/10.33373/simbio.v9i1.2423 